\title{
The Effects of Dairy Management on Milk Quality Characteristics
}

\author{
Pylyp Petrov*1, Yaroslava Zhukova ${ }^{1}$, Yuriy Demikhov²
}

${ }^{I}$ The Institute of Food Resources of The National Academy of Agrarian Sciences of Ukraine (4a M.Raskovoy street, Kyiv,Ukraine, 02002) ${ }^{2}$ The Institute of Environmental Geochemistry of The National Academy of Sciences of Ukraine (34a Palladin ave., Kyiv, Ukraine, 03680) A R T I C LE IN F O

A B S T R A C T
The article focuses on the impact of different dairy management types on quality
characteristics of organic and conventional milk. The study was conducted during 9
months (spring-autumn), raw milk samples were collected from organic and conventional
dairy farms from two Ukrainian regions. The milk samples were analyzed for dry matter,
total protein and non-protein nitrogen, ammonia content and values of stable isotopes
${ }^{13} \mathrm{C} /{ }^{12} \mathrm{C}$ were measured in fat and milk protein fractions. The values of dry matter, total
protein, true protein and non-protein nitrogen content do not represent a statistically
significant effect of farming type. The values of ammonia content, ammonia/non-protein
nitrogen and ammonia/total protein ratios were statistically significant and reflected the
impact of farming type which is, probably, linked with different protein content in cows'
diet. Conversion of some parameters on the dry matter allows more precise differentiation
among types of milk, including statistically significant differences (e.g. total protein and
ammonia content). The values of $\delta^{13} \mathrm{C}$ in fat fraction (-26.00\%o) and protein fraction
(-22.89\%) of organic milk were statistically significant differed in comparison with
conventional milk (-23.14 \%o and $-19.15 \%$ respectively), due to the high amount of maize
in the diet on conventional farm. The values of $\Delta \delta^{13} \mathrm{C}$ also were statistically significant:
$3.99 \%$ in conventional milk and $3.11 \%$ in organic. It was established that conventional
milk has a greater range of the different parameter seasonal variations than organic milk.

\section{Introduction}

In the past 20 years there has been a rapid growth in organic products market. The loss of faith to traditional (conventional) products, resulting from the detection of contaminants, pesticides, toxins etc. therein promotes this situation. In addition, the idea of healthy diet and environment protection, which are applicable to organic agriculture, are gaining popularity among consumers. Thus, in 2014 the European market turnover of organic products reached $€ 26.2$ billion, more than the previous year by $7.6 \%$. In particular, in Germany the turnover amounted to $€ 7.91$ billion, in France - $€ 4.83$ billion. In the US the turnover has reached $€ 27.06$ billion (Willer and Lernoud, 2016).

In Ukraine, the organic products market has been growing since the early 2000's and is increasing annually. According to the Swiss-Ukrainian project FIBL, Ukraine occupies the 11th place in Europe in terms of organic food production and by 2020 may become one of the five largest organic producers in the world. In 2014 in Ukraine 400,764 hectares were farmed organically, there were about 250 organic products producers and processors, and the internal market for organic products amounted to $€ 14.5$ million (Willer and Lernoud, 2016).

Despite the increase in the number of organic farms, which are certified according to respective requirements, comparative studies on the key indicators of conventional and organic products (e.g. milk and dairy products) are absent in Ukraine. Many of foreign works show the change of fatty acid composition of milk, depending on dairy management type. It is known that organic milk contains higher content of $\omega-3$ fatty acids, $\alpha$-linolenic acid, $\alpha$-tocopherol and Fe compared to conventional milk (Średnicka-Tober et al., 2016). However, there are significant differences in studies results, depending on the country of origin, animal's breed, season, diet etc. The comparison of the data on the concentrations of PUFA, $\omega$ 3 acids and CLA in organic and conventional cow's milk in different countries or geographic regions showed significant differences, and in some cases contradicting data has also been obtained in studies within the same country (Matt et al., 2011). At the same time, there are still less studies on the content of dry matter, total protein and other physical and chemical parameters of organic milk and the results are extremely ambiguous (Matt et al., 2011).

The aim of this work was to study the effect of the farming type (organic and conventional), as well as the season of the year on the physical-chemical and biochemical parameters of cow's milk in Ukraine, in particular the content of the nitrogen fractions and composition of stable isotopes ${ }^{13} \mathrm{C} /{ }^{12} \mathrm{C}$ in the protein and fat fractions of milk. 


\section{Materials and Methods.}

\section{Sample Collection}

Organic milk samples $(n=14)$ were collected on a certified high-input organic farm in Zhytomyr region of Ukraine, and conventional samples $(n=14)$ - on the conventional farm in Kyiv region of Ukraine. Both types of farm used the Simmental breed cows. Organic farm was certified by the Ukrainian certified body "Organic Standard, Ltd." (Kyiv, Ukraine). Bulk-tank milk samples were collecting during three seasons of 2015: indoorspring (March and April), outdoor (May-September) and indoor-autumn (October and November) and were transporting in ice to analysis. During the indoor period on organic farm the cattle diet consisted of organic hay, haylage and cereals (70\%), but also included maize silage, dry and canned maize, which accounted for $26 \%$. Compared to organic farm, the diet at the conventional farm contained a higher amount of maize silage (42\%), hay, silage, beets and carrots $-58 \%$. During the outdoor period on both types of farms the herds grazed on a pasture.

\section{Analysis of Milk Samples}

The milk samples were analyzed for the following parameters: dry matter ("Sartorius" MA-30, Germany), total protein and non-protein nitrogen (NPN) by the Kjeldahl method (ISO 8968: 2005-2,4, digester and distiller "Fisher Bioblock Scientific", Italy), ammonia content ("Biotronik", Germany), and the ratio of ${ }^{13} \mathrm{C} /{ }^{12} \mathrm{C}$ isotopes separately in fat and milk protein fractions (mass spectrometer MI-1201SG, Ukraine).

\section{Statistical Analysis}

The data were characterized using the mean and the standard deviation (SD). The impact of the "farming type" was evaluated using one-way analysis of variance (ANOVA) in MS Excel 2010. For all statistical tests, 5\% level of significance was used.

\section{Result and Discussion.}

Study of physical-chemical parameters of milk showed that the average dry matter within the study period was higher for the conventional milk (11.77\% vs. $11.41 \%$ in organic) (Table 1). This parameter for organic milk was higher in summer and autumn than in spring (5.2\% and $4.4 \%$ respectively), while for conventional milk it was higher in autumn than in spring and summer (1.4\% and $1.1 \%$ respectively). The data from Germany has shown similar results: higher amount of dry matter for the conventional milk $(13.9 \%)$ compared to organic (12.5\%) (Shröder et al., 2011). However, one group of Brazilian researchers reported about the equal amounts of dry matter for both milk types $(11.4 \%$ for conventional vs $11.5 \%$ for organic) (Olivo et al., 2005) and other group about higher amount in organic milk (12.68\% vs. $12.48 \%$ in conventional) (Kuhnen et al., 2015).

It was established that the value of total protein within the study period for organic milk samples was $3.15 \%$, while for conventional milk $-3.00 \%$ (Table 1). Our data are consistent with the authors from UK (Butler et al., 2008) and Brazil (Honorato et al., 2014). At the same time, the majority of studies indicates higher levels of total protein in conventional milk (Nauta et al., 2006; Kouřimská et al., 2014; Stergiadis et al., 2014; Kushe et al., 2014; Adler et al., 2006; Luukkonen et al., 2005; Battaglini et al., 2009; Kuhnen et al., 2015). Also, studies conducted in the US and Sweden had shown the lack of influence of farming on this parameter (Croissant et al., 2007; Toledo et al., 2002). Some authors explain the lower protein content in organic milk by the lower content of starch and sugar-rich sappy feed in the diet, which stimulate the formation of butyric acid necessary for protein synthesis (Kouřimská et al., 2014;. Zagorska and Ciprovica, 2008).

Table 1 The effect of dairy management and season on physical and chemical parameters of milk

\begin{tabular}{|c|c|c|c|c|c|c|c|}
\hline \multirow{2}{*}{ Parameter } & \multicolumn{2}{|c|}{ Spring } & \multicolumn{2}{|c|}{ Summer } & \multicolumn{2}{|c|}{ Autumn } & \multirow{2}{*}{ P-value } \\
\hline & Org & Conv & Org & Conv & Org & Conv & \\
\hline The dry weight & 11.04 & 11.70 & 11.64 & 11.74 & 11.55 & 11.87 & \multirow{2}{*}{0.53} \\
\hline$(\mathrm{g} / 100 \mathrm{~g})$ & \pm 0.05 & \pm 0.38 & \pm 1.04 & \pm 1.78 & \pm 0.05 & \pm 0.24 & \\
\hline Total protein & 2.94 & 3.04 & 3.31 & 3.04 & 3.20 & 2.94 & \multirow{2}{*}{0.16} \\
\hline$(\mathrm{g} / 100 \mathrm{~g})$ & \pm 0.63 & \pm 0.13 & \pm 0.13 & \pm 0.33 & \pm 0.18 & \pm 0.13 & \\
\hline Non-protein & 0.0249 & 0.0154 & 0.0313 & 0.0309 & 0.0245 & 0.0177 & \multirow{2}{*}{0.53} \\
\hline nitrogen $(\mathrm{g} / 100 \mathrm{~g})$ & \pm 0.001 & \pm 0.002 & \pm 0.017 & \pm 0.015 & \pm 0.001 & \pm 0.001 & \\
\hline NPN/TP \% & 4.81 & 3.24 & 5.99 & 6.27 & 4.93 & 3.97 & \multirow{2}{*}{0.70} \\
\hline 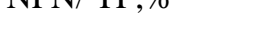 & \pm 0.34 & \pm 0.14 & $\pm 3,01$ & \pm 2.47 & \pm 0.47 & \pm 0.18 & \\
\hline True protein & 2.78 & 2.93 & 3.10 & 2.90 & 3.02 & 2.74 & \multirow{2}{*}{0.23} \\
\hline$(\mathrm{g} / 100 \mathrm{~g})$ & \pm 0.64 & \pm 0.13 & \pm 0.11 & \pm 0.25 & \pm 0.16 & \pm 0.13 & \\
\hline Ammonia & 0.1817 & 0.2021 & 0.2181 & 0.3702 & 0.1273 & 0.2459 & \multirow{2}{*}{0.02} \\
\hline$(\mathrm{mg} / 100 \mathrm{~g})$ & \pm 0.001 & \pm 0.003 & \pm 0.058 & \pm 0.108 & \pm 0.008 & \pm 0.179 & \\
\hline Ammonia/NPN \% & 0.73 & 1.31 & 0.85 & 1.40 & 0.52 & 1.39 & \multirow{2}{*}{0.01} \\
\hline AmImonra/NeIN, $\%$ & \pm 0.03 & \pm 0.02 & \pm 0.41 & \pm 0.66 & \pm 0.06 & \pm 1.01 & \\
\hline Ammonia/TP \% & 0.006 & 0.007 & 0.007 & 0.012 & 0.004 & 0.008 & \multirow{2}{*}{0.02} \\
\hline 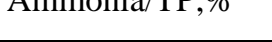 & \pm 0.001 & \pm 0.0002 & \pm 0.002 & \pm 0.004 & \pm 0.0007 & \pm 0.006 & \\
\hline
\end{tabular}

Data are represented as Means $\pm \mathrm{SD}, \mathrm{P} \leq 0.05$. Org - organic milk, Conv - conventional milk. 
Table 2 Effect of dairy management and season on the $\delta^{13} \mathrm{C}$ in milk

\begin{tabular}{|c|c|c|c|c|c|c|c|}
\hline \multirow{2}{*}{$\delta^{13} \mathrm{C}, \%$} & \multicolumn{2}{|c|}{ Spring } & \multicolumn{2}{|c|}{ Summer } & \multicolumn{2}{|c|}{ Autumn } & \multirow{2}{*}{ P-value } \\
\hline & Org & Conv & Org & Conv & Org & Conv & \\
\hline \multirow{2}{*}{ Fat fraction } & -25.80 & -20.60 & -26.49 & -25.73 & -25.70 & -23.10 & \multirow[b]{2}{*}{0.03} \\
\hline & \pm 0.29 & \pm 0.26 & \pm 1.35 & \pm 1.70 & \pm 0.38 & \pm 0.27 & \\
\hline \multirow{2}{*}{ Protein fraction } & -22.54 & -15.50 & -23.80 & -22.34 & -22.80 & -19.60 & \multirow{2}{*}{0.01} \\
\hline & \pm 0.37 & \pm 0.14 & \pm 1.18 & \pm 1.02 & \pm 0.17 & \pm 0.21 & \\
\hline \multirow{2}{*}{$\Delta \delta^{13} \mathrm{C}$} & 3.52 & 5.10 & 2.34 & 3.61 & 2.80 & 3.50 & \multirow{2}{*}{0.01} \\
\hline & \pm 0.12 & \pm 0.07 & \pm 0.85 & \pm 0.94 & \pm 0.15 & \pm 0.11 & \\
\hline
\end{tabular}

Data are represented as Means $\pm \mathrm{SD}, \mathrm{P} \leq 0.05$. Org - organic milk, Conv - conventional milk.

Our study was shown that total protein amount had seasonal variations: in organic milk this parameter was higher in summer and autumn than in spring (by $11.2 \%$ and by $8.1 \%$, respectively); in conventional - the equal amount in spring and summer and higher than in autumn (by 3.3\%). These findings agree with the Italian study, that showed that total protein value during the grazing period was higher than during the indoor period for organic milk by $3.6 \%$ and for conventional - by $3.5 \%$ (Battaglini et al., 2009). However, the study conducted in the UK revealed that in conventional milk values of total protein were equal in winter and summer, whereas for organic milk this parameter was higher in summer than in winter by $2.9 \%$ (Butler et al., 2008). According with the Finnish study there were no significant seasonal variation: for organic milk the summer values were higher than the winter only by $1.2 \%$, and for conventional milk these values were equal (Luukkonen et al., 2005). Polish researchers report that the of total protein values during the early indoor period were higher than during the late grazing period by $3.0 \%$ for conventional and by $9.4 \%$ for organic milk (Kuczynska et al. 2012). Also, the study of organic milk in Poland showed that total protein values were higher in winter than in summer, with the average value of $8.1 \%$ (Kuczynska et al., 2011). So, total protein values vary greatly depending on geographical origin, climatic conditions and feeding.

Non-protein nitrogen (NPN) is an important indicator of milk quality. NPN includes different nitrogen compounds (urea, uric acid, creatine, creatinine, free amino acids and nucleic acids) which are not precipitated by trichloroacetic acid (McSweeney and Fox, 2003). Urea can comprise up to a half of the total NPN fraction and is directly correlated to the urea content in cow's blood, which level is also dependent on the diet. Particularly, the high protein and minimal grain contents in the diet increase the level of non-protein nitrogen (Harding, 2013).

Our data showed that NPN values in organic milk $(0.0269 \mathrm{~g} / 100 \mathrm{~g})$ were higher than in conventional $(0.0213 \mathrm{~g} / 100 \mathrm{~g})$ on average by $20.8 \%$. Also, we have detected the seasonal variations of NPN values: they were higher in summer than in spring and in autumn in organic milk (by $20.4 \%$ and $21.7 \%$ respectively) and in conventional - by $50.2 \%$ and $42.7 \%$ respectively. The biggest difference of NPN content in organic and conventional milk was in spring and autumn.

The variation of nitrogen fraction content can indicate the effectiveness of feed protein digestion. The ratio of
NPN to total nitrogen (TN) was higher in organic milk $(5.49 \%)$ than in conventional $(4.53 \%)$. It was higher in organic milk in summer than in spring (by $7.3 \%$ ) and autumn (by 17.7\%), while in conventional this variation was more appreciable (by $46.7 \%$ and $36.7 \%$ respectively).

The determination of actual content of casein and whey proteins in milk could be evaluated by the calculation of true protein value that is crucial for cheese making. The true protein content was calculated by subtraction of non-protein nitrogen from total nitrogen and subsequent multiplication by a factor of 6.38 (Harding, 2013). The average value of true protein content within the study period was higher in organic milk $(2.93 \%)$ than in conventional $(2.86 \%)$. As it has already been shown in our study, NPN content varied depending on the season, that is correlated with true protein content. True protein values in organic milk were higher in summer than in spring and autumn (by $10.3 \%$ and by $2.6 \%$ respectively), while in conventional - equal in spring and summer and higher than in autumn by $6.2 \%$.

The ammonia content in raw milk is generally $0.3-1.0$ $\mathrm{mg} \%$ and may increase during storage due to the development of foreign microflora and activity of their dehydrogenases, transferases and other enzymes (Gorbatova and Gun'kova, 2010). According to our study, the mean value of ammonia during the study period was higher in conventional milk $(0.273 \mathrm{mg} / 100 \mathrm{~g})$ than in organic $(0.176 \mathrm{mg} / 100)$ and this difference was shown to be statistically significant. Summer values of ammonia content were higher than spring and autumn in organic milk by $16.7 \%$ and $41.6 \%$ respectively and in conventional milk - by $45.4 \%$ and $65.6 \%$, respectively. The ratio of ammonia value to the NPN value can represent the impact of dairy management and season on milk quality. The difference between average values of ammonia to NPN ratio of organic $(0.7 \%)$ and conventional (1.37\%) milk was estimated to be statistically significant. The highest values were recorded for organic milk summer samples and they were higher compared to spring and autumn values by $14.1 \%$ and $22.4 \%$ respectively. Meanwhile in conventional milk in summer and autumn period the values were equal and exceeded the spring period value by $6.4 \%$. The ratio of ammonia to total protein values of organic milk $(5.6 \%)$ was lower than in conventional $(9.0 \%)$ and this difference was also shown to be statistically significant. In organic milk seasonal dynamics haven't been observed, while in conventional milk summer values were higher than spring and autumn by $41.7 \%$ and $33.3 \%$ respectively. 
Conversion of the analyzed parameters on dry matter weight can support more objective differentiation of milk depending on the farming type. Conversion of total protein on dry matter weight showed a statistically significant difference. The mean values for the analyzed period were higher in organic milk $(27.59 \%)$ in comparing with conventional $(25.55 \%)$. In organic milk it was observed a seasonal dynamic: summer values were higher than spring and autumn by $6.4 \%$ and $2.6 \%$ respectively, while in conventional milk season dynamic was negligible.

Conversion of NPN content on dry matter weight in average was higher in organic milk $(0.236 \%)$ than in conventional $(0.181 \%)$. These values also had a seasonal trend and were higher in summer than in the spring and autumn in milk of both types. In organic milk - by $16.00 \%$ and $21.19 \%$, while in conventional - by $49.81 \%$ and $43.35 \%$ respectively.

Conversion of the true protein on dry matter showed higher values (by 6.62\%) in organic milk (25.99\% vs. $24.27 \%$ in conventional). This parameter in organic milk was higher in summer than in spring and autumn by $5.4 \%$ and $1.8 \%$ respectively, while in conventional milk higher in spring than in summer and autumn by $1.4 \%$ and $7.8 \%$ respectively.

Conversion of ammonia on dry matter showed a statistically significant difference between two types of farming. Average value for the study period was higher in conventional milk $(0.0023 \%)$ compared to organic milk $(0.0015 \%)$. Also, the higher seasonal dynamic was observed in conventional milk: summer values were higher than spring and autumn by $46.9 \%$ and $34.4 \%$ respectively, and in organic - by $15.8 \%$ and $42.1 \%$.

The ${ }^{13} \mathrm{C} /{ }^{12} \mathrm{C}$ stable isotope ratio (expressed as $\delta^{13} \mathrm{C}$ ) is related to the quantity of maize, which is an important constituent of cows' diet (Bontempo et al., 2012). According to organic farming rules the cattle diet should predominantly consist of fresh grass and hay (the plants with $\mathrm{C}_{3}$-type of photosynthesis). Conventional farming system diet is mainly represented by maize silage (the plant with $\mathrm{C}_{4}$-type of photosynthesis) and concentrates. Consequently, the values of $\delta^{13} \mathrm{C}$ in milk may represent the proportion of plants with $\mathrm{C}_{3^{-}}$and $\mathrm{C}_{4}$-type of photosynthesis in cows' diet. The value of $\delta^{13} \mathrm{C}$ increases with a higher amount of maize in diet and decreases with a higher amount of hay and fresh grass (Camin et al., 2008; Bontempo et al., 2012; Kaffarnik et al., 2014). More accurate results can be obtained by means of calculating the values of $\delta^{13} \mathrm{C}$ for the extracted milk lipid fraction rather than for whole milk, whereas the content of fat in milk or the ratio between fat and protein can influence the results of measurement (Molkentin and Giesemann, 2007).

According to our results (Table 2), the average values of $\delta^{13} \mathrm{C}$ in organic milk fat fractions $(-26.00 \%$ ) were significantly lower than in conventional (-23.14\%o). Within the test period, the values in summer samples were lower than in spring and autumn samples in both milk types (in organic milk by $2.6 \%$ and $3.0 \%$, while in conventional - by $19.9 \%$ and $10.2 \%$ respectively). Our data comply with German studies claiming that the average values of $\delta^{13} \mathrm{C}$ in fat fraction of organic milk range from $-26.5 \%$ (Molkentin, 2013) to $-28.0 \%$ (Molkentin and Giesemann, 2007) or even -29.41\%o (Molkentin, 2009), and in conventional milk it amounts 26.6\% (Molkentin and Giesemann, 2007). However, the Italian study of summer milk from alpine mountain farms with a diet based only on $\mathrm{C}_{3}$-type plants showed mean values at -23.5\%o (Bontempo et al., 2012), which can also indicate the impact of geographical origin and altitude on the isotopic profile.

Analysis of $\delta^{13} \mathrm{C}$ values in milk protein fraction showed that in organic milk they were significantly lower $(-23.05 \%)$ than in conventional $(-19.15 \%$ ) (Table 2$)$. For organic milk $\delta^{13} \mathrm{C}$ values of summer samples were lower than that of spring and autumn samples by $5.3 \%$ and $4.2 \%$ whereas for conventional milk the difference was $30.6 \%$ and $12.3 \%$ respectively. This trend can be explained by a significant decrease in the amount of maize in diet during summer, as evidenced by a large difference in results between outdoor and indoor periods.

Thus, the maximum difference of $\delta^{13} \mathrm{C}$ values between two periods was observed for milk protein fraction compared to fat fraction, that shows greater influence of the diet (in particular, maize amount) exactly on milk protein fraction. Lower variability of $\delta^{13} \mathrm{C}$ throughout the study period in organic milk indicates that the diet consisted mainly of plants with $\mathrm{C}_{3}$-type of photosynthesis.

A distinctive feature of conventional milk is a significantly higher value of $\Delta \delta^{13} \mathrm{C}$ (difference between $\delta^{13} \mathrm{C}$ fat fraction and $\delta^{13} \mathrm{C}$ protein fraction) which was $4.07 \%$, while in organic milk $-2.89 \%$. Values $\delta^{13} \mathrm{C} \Delta \delta^{13} \mathrm{C}$ in conventional milk were higher in spring $(5.10 \%$ ) than in summer and autumn (3.61\% and $3.50 \%$ respectively). The same trend was observed in organic milk - spring values $(3.52 \%$ ) were higher than in summer and autumn ( $2.54 \%$ and $2.80 \%$ respectively).

\section{Conclusions}

It was established that conventional milk has a greater range of different parameter seasonal variations than organic milk. In summer, with a change in diet due to grazing on pasture, many parameters of conventional milk have become similar to organic milk. The main differences in the obtained data were observed in spring and autumn, during indoor period, due to the different diet on organic and conventional farms. Possibly, parameters with statistical significance, such as ammonia content, ammonia/non-protein nitrogen and ammonia/total protein ratios, $\delta^{13} \mathrm{C}$ and $\Delta \delta^{13} \mathrm{C}$ may be considered as the markers of organic milk authenticity and can be useful for the differentiation of organic and conventional farming types.

\section{Acknowledgements}

The authors give thanks to "Organic Milk, Ltd." company and personally to E. Stretovych for providing samples from organic farm and to Mr. Listopad F. and Mrs. Borisova N. for their skilled assistance in conducting experiments. 


\section{References}

Adler SA, Jensen SK, Govasmark E, Steinshamn H. 2013. Effect of short-term versus long-term grassland management and seasonal variation in organic and conventional dairy farming on the composition of bulk tank milk. J. Dairy Sci., 96: 5793-5810.

Battaglini L, Renna M, Garda A, Lussiana C, Malfatto V, Mimosi A, Bianchi M. 2009. Comparing milk yield, chemical properties and somatic cell count from organic and conventional mountain farming systems. Ital. J. Anim. Sci., Vol. 8 (Suppl. 2): 384-386.

Bontempo L, Lombardi G, Paoletti R, Ziller L, Camin F. 2012. H, $\mathrm{C}, \mathrm{N}$ and $\mathrm{O}$ stable isotope characteristics of alpine forage, milk and cheese. International Dairy Journal, 23: 99-104.

Butler G, Nielsen J, Slots T, Seal C, Eyre M, Sanderson R, Leifert C. 2008. Fatty acid and fat-soluble antioxidant concentrations in milk from high- and low-input conventional and organic systems: seasonal variation. Journal of the Science of Food and Agriculture, Vol.88:1431-1441.

Camin F, Perini M, Colombari G, Bontempo L, Versini G. 2008. Influence of dietary composition on the carbon, nitrogen, oxygen and hydrogen stable isotope ratios of milk. Rapid Commun. Mass Spectrom., 22: 1690-1696.

Croissant A, Washburn S, Dean L, Drake M. 2007. Chemical Properties and Consumer Perception of Fluid Milk from Conventional and Pasture-Based Production Systems. J. Dairy Sci., 90: 4942-4953.

Harding F. 2013. Milk Quality. Springer. ISBN 1461521955, 9781461521952

Honorato L, Machado Filho L, Barbosa Silveira I, Hötzel M. 2014. Strategies used by dairy farmers in the south of Brazil to comply with organic regulations. J. Dairy Sci, 97: 1319-1327.

Kaffarnik S, Shröder M, Lehnert K, Baars T, Vetter W. 2014. $\delta^{13}$ C values and phytanic acid diastereomer ratios: combined evaluation of two markers suggested for authentication of organic milk and dairy products. Eur Food Res Technol, 238: 819-827. DOI 10.1007/s00217-014-2158-3

Kuczyńska B, Nałęcz-Tarwacka T, Puppel K, Gołebiewski M, Grodzki H, Slósarz J. 2011. The content of bioactive components in milk depending on cow feeding model in certified ecological farms. J. of Research and Applications in Agriculture Engineering, Vol. 56(4): 7-13.

Kuczyńska B, Puppel K, Gołebiewski M, Metera E, Sakowski T, Słoniewski K. 2012. Differences in whey protein content between cow's milk collected in late pasture and early indoor feeding season from conventional and organic farms in Poland. J Sci. Food Agric., Nov, 92(14): 2899-904. doi: $10.1002 /$ jsfa.5663.

Kuhnen S, Stibuski R, Honorato L, Pinheiro Machado L. 2015. Farm Management in Organic and Conventional Dairy Production Systems Based on Pasture in Southern Brazil and Its Consequences on Production and Milk Quality. Animals, 5: 479-494. doi:10.3390/ani5030367

Kouřimská L, Legarová V, Panovská Z, Pánek J. 2014. Quality of Cows' Milk from Organic and Conventional Farming. Czech J. Food Sci., 32: 398-405.

Kushe D, Kuhnt K, Ruebesam K, Rohrer C, Nierop A, Jahreis G, Baars T. 2014. Fatty acid profiles and antioxidants of organic and conventional milk from low-and high-input systems during outdoor period. Journal of the Science of Food and Agriculture, Vol.95., Issue 3: 529-539.

Luukkonen J, Kemppinen A, Karki M, Laitinen H, Maki M, Sivela S, Taimisto A-M, Ryhanen EL. 2005. The effect of a protective culture and exclusion of nitrate on the survival of enterohemorrhagic E. coli and Listeria in Edam cheese made from Finnish organic milk. International Daily J., 15: 449-457.
Matt D, Rembialkowska E, Luik A, Peetsmann E, Pehme S. 2011. Quality of Organic vs. Conventional Food and Effects on Health. Estonian University of Life Sciences. ISBN 978-9949484-06-5

McSweeney P, Fox P. 2003. Advanced Dairy Chemistry: Volume 1: Proteins, Parts A\&B: Protein. Springer Science \& Business Media. ISBN 0306472716, 9780306472718

Molkentin J. 2009.Authentication of Organic Milk Using $\delta^{13} \mathrm{C}$ and the $\alpha$-Linolenic Acid Content of Milk Fat. J. Agric. Food Chem, 57: 785-790

Molkentin J. 2013. Applicability of organic milk indicators to the authentication of processed products. Food Chemistry, 137: 2530 .

Molkentin J, Giesemann A. 2007. Differentiation of organically and conventionally produced milk by stable isotope and fatty acid analysis. Anal Bioanal Chem, 388:297-305. DOI 10.1007/s00216-007-1222-2

Nauta W, Veerkamp R, Brascamp E, Bovenhuis H. 2006. Genotype by Envirnoment Interaction for Milk Production Traits Between Organic and Conventional Dairy Cattle Production in The Netherlands. J. Dairy Sci, 89: 2729-2737.

Olivo C, Beck L, Gabbi A, Charão P, Sobczak M, Uberty L, Dürr J, Filho R. 2005. Composition and somatic cell count of milk in conventional and agro-ecological farms: a comparative study in Depressão Central, Rio Grande do Sul state, Brazil. Livestock Research for Rural Development, Vol.17, Article \#72. Available from: http://www.lrrd.org/lrrd17/6/oliv17072.htm [Accessed 1.03.16].

Shröder M, Yousefi F, Vetter W. 2011. Investigating the day-to-day variations of potential marker fatty acids for organic milk in milk from conventionally and organically raised cows. Eur Food Res Technol, 232: 167-174.

Średnicka-Tober D, Barański M, Seal C, Sanderson R, Benbrook C.. Steinshamn H., Gromadzka-Ostrowska J., Rembiałkowska E., Skwarło-Sońta K., Eyre M., Cozzi G., Larsen M.K., Jordon T., Niggli U., Sakowski T., Calder P.C., Burdge G.C., Sotiraki S., Stefanakis A., Stergiadis S., Yolcu H., Chatzidimitriou E., Butler G., Stewart G., Leifert C.2016. Higher PUFA and n-3 PUFA, conjugated linoleic acid, $\alpha$-tocopherol and iron, but lower iodine and selenium concentrations in organic milk: a systematic literature review and meta- and redundancy analyses. British Journal of Nutrition, Mar, 115(6): 1043-60. doi: 10.1017/S0007114516000349

Stergiadis S, Leifert C, Seal C, Eyre M, Steinshamn H, Butler G. 2014. Improving the fatty acid profile of winter milk from housed cows with contrasting feeding regimes by oilseed supplementation. Food Chemistry, 164: 293-300.

Toledo P, Andrén A, Björck L. 2002. Composition of raw milk from sustainable production system. International Dairy Journal, 12: 75-80.

Willer H, Lernoud J. 2016. The World of Organic Agriculture. Statistics and Emerging Trends 2016. Research Institute of Organic Agriculture (FiBL), Frick and IFOAM - Organics International, Bonn. ISBN FiBL 978-3-03736-307-2 - ISBN IFOAM 978-3-944372-15-0

Zagorska J, Ciprovica I. 2008. The chemical composition of organic and conventional milk in Latvia. 3rd Baltic Conference on Food Science and Technology FOODBALT-2008. Conference Proceedings. Jelgava, LLU, 2008. P.10-14. ISBN 978-9984784-69-4

Gorbatova K, Gun'kova P. 2010. Biohimija moloka i molochnyh produktov. 4 e izd. GIORD, Saint-Petersburg. 